\title{
DIGITAL APPLICATION USAGE TO MANAGE FAMILY BUSINESS FINANCES IN KELURAHAN NORTH KEMBANGAN, WEST JAKARTA
}

\author{
Mafizatun NURHAYATI ${ }^{1}$, Ahmad BADAWI ${ }^{2}$, Nurul HIDAYAH ${ }^{3 *}$ and Zamri AHMAD ${ }^{4}$ \\ 1,2,3 Universitas Mercu Buana \\ ${ }^{4}$ University Sains Malaysia \\ mafizatun.nurhayati@mercubuaa.ac.id a.badawi@mercubuana.ac.id*nurul.hidayah@mercubuana.ac.id \\ zahmad@usm.my
}

\begin{abstract}
The COVID-19 pandemic has drastically affected the Indonesian economy. Indonesia economic facing slowdown last year and is expected to remain under pressure in 2021. Sectors requiring direct interactions have been the hardest hit, such as tourism, transportation, logistics, as well as hospitality industry. With the economy taking a downturn path, millions of Indonesians are at risk of losing their jobs. Much of the unemployment rise will happen in the Micro, Small, and Medium Enterprises (MSMEs), a key sector that accounts for about 61 percent of the country's Gross Domestic Product (GDP). Family business as a MSMEs in the COVID 19 have to survive their business and manage their income for the expenditure all day. But many little business have difficulty in managing their income because they do not know how to manage and arrange money and control the net income or lost. These small entrepreneurs think that the income they receive can be used for their daily needs without realizing that the income and profits earned should be separated to develop a family business. Family businesses, especially those carried out by housewives, do not know how to use the income and how to manage finances, because there is no good record keeping.They need financial planning for the activities related to the business and can manage as good as possible. Therefore the community service activity needs to be carried out and aims to provide knowledge, especially for family businesses to be able to manage their finances properly. This community program have a purpose to educate how to manage their family financial management based on digital application easily learned and mastered.
\end{abstract}

Keyword : Family Business, Financial Planning, Financial Management, Digital Application

\section{BACKGROUND}

UNDP Indonesia Resident Representative (2020) explain that MSMEs play an influential role in the Indonesian economy. In 2016, the financial contribution of MSMEs to the GDP of Indonesia increased to $60.34 \%$. Furthermore, these enterprises play an important role by providing $97 \%$ of the employment opportunities (BPS, 2016). During economic turmoil, especially during the 1997-1998 Asian economic crisis, MSMEs have shown tremendous resilience, and have performed better in terms of crisis management compared to medium-sized and large businesses. The COVID-19 pandemic has significantly affected the global economy, including Indonesia. This outbreak might push the Indonesian economy into another crisis, possibly deeper than the 1997-1998 Asian financial crisis because it affects both demand and supply. Statistics Indonesia (BPS) announced that Indonesia's economy grew by $(-5.32 \%)$ in the second quarter of 2020 . In the full year of 2020, several prominent financial organizations expected Indonesia's GDP to contract: IMF $(-0.3 \%)$, ADB (-1\%), World Bank (-2\%), and OECD (-2.8-3.9\%). The problems faced by MSMEs in Indonesia due to the COVID-19 pandemic require special attention. Around $98.68 \%$ of approximately 64 million MSMEs in Indonesia are self-employed micro businesses that are vulnerable to internal and external economic shocks. While small enterprises constitute only $1.2 \%$, and medium-sized enterprises constitute even less. Despite the importance of MSMEs in Indonesia, the extent of the impact of the pandemic on these enterprises is still unknown. Moreover, there is still no clear strategy to mitigate the impact and to speed up the recovery after the pandemic. Nonetheless,
MSMEs and their employees need support to survive the COVID-19 pandemic.

The Covid-19 pandemic which began to hit all regions of the world including Indonesia at the end of 2019 had a serious impact on various industrial fields and regions such as health, economy, transportation, and other fields (Shen et al., 2020). Population mobility has dropped sharply due to the quarantine policy which has weakened purchasing power and a stagnant economy. While at the macro level, the COVID-19 outbreak caused the worst global recession since 1930, when the economy was completely shaken. China's gross domestic product fell by $6.8 \%$ in the first quarter compared to the same period last year, 1 and many countries experienced severe corporate bankruptcies and job losses (H., 2020). This condition exacerbates household economic conditions. Report by the United Nations Development Program (UNDP) and the University of Indonesia's Institute for Economic and Social Research (LPEM). The report also further emphasizes the ferocity and depth of the Covid-19 pandemic on the Indonesian economy, which experienced a slowdown in 2020. The findings of this report are that women entrepreneurs who generally have unequal access to finance also experience a decline. More than $37 \%$ of MSMEs owned by women experienced income losses of between $40-60 \%$. The report also reveals that around $44 \%$ of MSMEs turn to online platforms to sell their products through e-commerce modules. "Social media especially Instagram is filled with young and independent entrepreneurs selling their innovative products from home wear to food. 


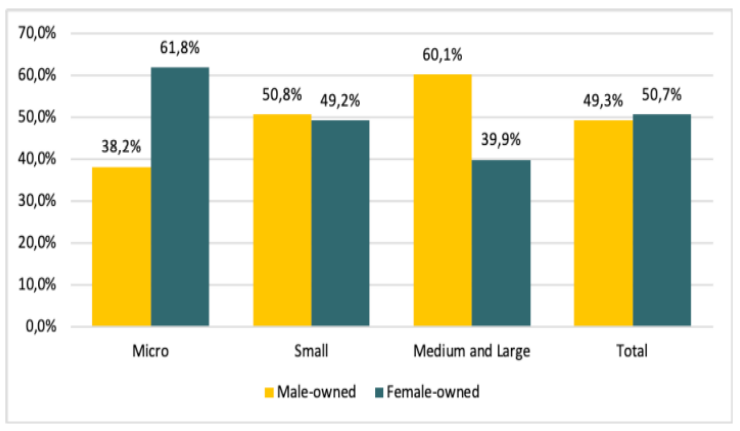

Figure 1. MSMEs Gender

Source UNDP 2020

At Figure 1 above, In terms of the owner's gender, most MSMEs were owned by women $(50,7 \%)$, while male ownership was around $49.3 \%$. Medium and large enterprises surveyed were largely owned by men $(60 \%)$, while male ownership of small enterprises was slightly higher $(51 \%)$ than that of women $(49 \%)$. are more prominently represented $(62 \%)$ than male-owned micro businesses (38\%).

Even though it's still a pandemic, family business have to survive their business. Family businesses are more than entrepreneurial endeavors. Family business need an emotional investment, creating deep personal ties with relatives, employees, and community. Is it possible to scale and expand one without losing those ties and the personal touch that made a success. Family business can create systems that anyone can follow for key tasks like onboarding new customers, marketing updates.

Around $40 \%$ of MSMEs had been selling or planning to sell their products through the online marketplace and one of the alternative strategies adopted by MSMEs to minimize their expenses in the short term was by reducing consumption of utilities, thus lowering their expenses (e.g. electricity, water, gas, and communication). As a financial manager in the household, it is hoped that they will be wise in managing household income and expenses. However, most Housewife experience difficulties in managing household finances because they do not know how to manage money and control their desires or passions (Budiantoro et al., 2019). Financial planning is needed to regulate activities related to financial management. Household as financial manager in family expected wise in arranging family income. Many mothers have difficulty in managing the family finances is not because they do not know how to arrange money and control the desire or lust. Financial planning is needed to regulate the activities related to financial management. Ridwan (2015) argues each allocating family income and expenditure efficiently and effectively to achieve his objectives family financial goals. Family financial management objectives, namely the balance between revenue and expenditure. The key drivers in family problems are the mothers owe to cover expenses for family consumption, this condition arises because imbalance between income and expenditure and ignorance in the family's financial arrangements The purpose of household financial management is too reach a balance between income and expenditure. The main driver of family problems is the obligation of housewife to cover household consumption expenses, this condition arises because of an imbalance between income and expenditure and ignorance of household financial arrangements.

Danes \& Hira (1987) states learn to manage money is just as important to get it. Financial problems related to the everyday and financial management is a classic problem in life. The financial crisis is not due to a lack of income but often because of improper financial arrangements. Everyone is expected to manage personal and household financial so well that revenue and expenditure can be balanced. The benefits of the money could be increased if financial management is applied through the right way that contributes to the high welfare to be useful (Sumiarni, 2019). Money is an important factor in daily life because of the money that can be met livelihood of a person. Money is earned through hard work is one of the reasons a person. Various methods are used to improve the income fulfilled sehungga economic life of a person. There is a software application that became a front end in a system used to process data into a useful information for people and systems concerned (Williams et al., 2009). The term comes from the English application means application deployment, application or use. While the term, meaning the application is a program that is ready to be used are made to perform a function for the user application services and the use of other applications that can be used by a target that will be addressed (Burgess \& Paguio, 2016).

According to the executive computer dictionary, the application has the meaning that is solving problems using one of the techniques of data processing applications are usually raced on a computation the desired or expected and the expected data processing (Drotar, 2011). Is a software application that is used for specific purposes, such as processing documents, organize Windows \& Games (games), and so on. Some applications are merged together into a package called a packet or application suite. Aplikasi-applications in a package usually has a user interface with the same making it easier for users to learn and use each application.

Scheme of Financial Statements The Financial Applications are designed to assist and facilitate the performance of the wearer (Putra, 2019). In the accounting system, manual work processes occur only at the beginning, ie at the stage of inputting financial transactions. For later stages, until the financial statements to be done automatically by the system and applications (Rekarti \& Doktoralina, 2017). So when there is a transaction that is in the input will automatically occur the process of preparing financial statements. This will greatly help in controlling the financial position, due to the latest financial reports can be viewed at any time with a smartphone in hand. In the financial recording using Financial Applications 
on smartphones Mothers training participants located in North Kembangan, things that need to be done first is the installation of an application program, free of charge. Based on the explanation above, it is deemed Necessary to hold family financial management training based on mobilephone usage in North Kembangan by breaking down the following problems:

1. How to operate smartphone aplicationfor to manage the financial of business?

2. How can a financial management based on smartphone be effective and evaluated.

\section{Solution And Outcome Target}

In order to provide solutions for family business problem, the community service activities are carried out by providing training to participants in the form of knowledge about financial management through applications from smart phones which are very helpful for recording all transactions both sales and expenses in an easy way.

The method of implementing this activity is carried out by online seminars. The activity consist of giving lectures, knowledge sharing, implementing strategies, and providing motivation to grow an entrepreneurial spirit early on.

To solve the problem of the financial management in Family, The community service team give the training activities that have targets items, namely:

a. Increased insight and understanding in family financial management, especially little business in North Kembangan.

b. Increased knowledge about the financial management of the family-based on digital application as well as be able to practice that knowledge in everyday life .

And the outcome target are:

1. The results of this activity will be disseminated and submitted in the Community Service Journal

2. This activity is an aid to business increasing knowlodge their work with mastery of technology including in mastering family financial management based on mobilephone.

\section{METHOD}

The purpose of community service activity is will help the family especially to develop how to manage financial business and provide knowledge how to use digital application to manage their family financial. In this case the purpose also to enhance their skill to manage their financial.

The benefits of community service activities in this regard are:

1. Assist the mother to literate Reviews their family financial management.

2. Provide mothers to have information technology expertise.
3. Provide mother to prepare financial reports appropriately, quickly intervening and realtime.

The way to achieve a more prosperous person is to manage finances wisely and carefully. One effort that can be done is to make financial records so that they can be controlled properly. Benefits and at any time can be record as reference material for finance to recovery. Thesefinancial records can help a person to remain stable financially so they can see whether there needs to be improvements that increase savings. The activity is in the form of exposure to the which includes guidance on financial managrement running family-based on digital application that are assisted by tutors and provide an overview of the ease of use the online financial management and the results of presentation of teaching material that is more interesting.

After the presentation materials, the training of participants in the second session were guided to directly practice the material available. In the Midst of the training all of participants were free to ask questions about the financial management. Sharing knowledge how to use digital application to manage their financial.

\section{RESULTS AND DISCUSSION}

\section{Results}

This activity named International joint community services between Universitas Mercu Buana and Universiti Sains Malaysia aims to improve the quality of academic activity and provide additional benefits to both universities. The activities joint community services are held in one day on February 8th, 2021 were located in North Kembangan ,West Jakarta and using virtual room (Zoom Meeting). The implementation of PPM activities on that day was attended by more than 100 participants from several SME and family business player from such North Meruya and South Meruya.

The age of the participants and types of side businesses and their education are as follows:

Table 1 Type of business and education participant

\begin{tabular}{|c|c|c|c|}
\hline $\begin{array}{c}\text { Side } \\
\text { Business }\end{array}$ & $\begin{array}{c}\text { Amount/ } \\
\text { Percentage }\end{array}$ & Education & $\begin{array}{c}\text { Amount/ } \\
\text { Percentage }\end{array}$ \\
\hline $\begin{array}{c}\text { Food/ } \\
\text { Baverage }\end{array}$ & $64 / 64 \%$ & $\begin{array}{c}\text { Junior high } \\
\text { school }\end{array}$ & $32 / 32 \%$ \\
\hline $\begin{array}{l}\text { Household } \\
\text { Appliance }\end{array}$ & $24 / 24 \%$ & $\begin{array}{c}\text { Senior high } \\
\text { school }\end{array}$ & $48 / 48 \%$ \\
\hline Others & $12 / 12 \%$ & $\begin{array}{l}\text { Bachelor/ } \\
\text { Undergrad }\end{array}$ & $20 / 20 \%$ \\
\hline Total & $50 / 100 \%$ & & $50 / 100 \%$ \\
\hline
\end{tabular}

Furthermore, following table 1 above, it is known that the majority of participants in the socialization are family business in food/beverage side, which also becomes their hobby of $64 \%$. The side business of selling household appliance and others for the daily needs of their families income. Furthermore, according to Saragih 
(2017) if the hobbies and expertise are combined, the services or products produced will be of high quality as many as majority of the participants. In terms of education, the majority of participants are senior high school, which is $48 \%$ of the participants but they concern to improve the welfare of their families which is also supported by their higher knowledge. participants are also given knowledge about strategies to keep the family business growing. Several strategies for family business as follow: (Hutcheson,2008)

1. keep the lines of communication open.

Schedule regular family meetings to discuss issues of concern as well as key topics such as performance and transition. Include all the family members, no matter where in the hierarchy their jobs fall — exclusion creates animosity. Create a family manual that lays out the ground rules for how the meetings will take place to ensure that everyone gets a chance to be heard and impediments to communication are left at the door.

2. Assign clear roles and responsibilities.

As a family member, it's natural to feel that everything is family business. However, not everything is every family member's responsibility. Job definitions prevent everyone from jumping in to tackle the same problem, and help ensure that the business runs smoothly.

3. Keep good financial data.

The downfall of many small businesses and family businesses is not having solid data. Designate a single point of contact to manage the finances. If you're small enough, you can rely on a family member. Otherwise, you'll need to bring in a qualified accountant. You may cringe at the expense for this, but the difference between a good accountant and a bad one is the difference between knowing exactly where you are on the road and trying to drive with a mud-covered windshield.

4. Avoid overpaying family members.

Market-based compensation is fundamental and essential. Parents in family businesses tend to either overpay the next generation or pay everyone equally despite differing levels of responsibility. Both are bad practices. The longer unfair compensation practices continue, the messier it will be to clean up when it blows up.

5. Don't hire relatives if they're unqualified.

Family businesses are a conundrum: The family aspect generates unqualified love, while the business side cares about profits. Thus, family members will be hired to provide them with a job, even though they're not qualified. The remedy is to get them trained, move them to a role that matches their skills, or have them leave.

On this occasion, the training instructor provided material that discussed how to manage SME business was sustainable. Several factors was keep personal lives out of business like cash flow management, customer experience, and generating sales. Second understand the generation gap Some of employees/family members will have more experience than others and, depending on the roles that they fill, they might not be as up-to-date with what customers expect it. Third is always maintaining good governance between carrying out a routine recording of the income and expenses that occurred. Positive cashflow when receive more income than pay out in expenditure, must be maintained. Recording all of days transaction, that can be done through the software contained in the apps store application on the smart phone. Furthermore, discussions and questions and answers were held with the participants.

Financial documents have a crucial part to play in any small business. They have a wide range of uses, from the internal tracking of revenue and expenses to proving the viability of business to investors and finance providers. Keeping on top of financial planning and forecasting will also help to identify potential issues before they arise and allow to make more informed decisions about the direction the business will take.

\section{Discussion}

The Joint community service activities that have been carried out include the presentation and discussion. Discussion and answer many questions posed to the instructor is related how to measure sales profit which has been unknown because it is mixed between personal and SME expenditure and business income. Instructor provide an explanation to identify between personal and business income and expenses. Everyday all of SME transaction need to record, in order to known about the progress obtained. Recording of SME transactions can now be done very easily by utilizing a digital application from a smartphone. This activity completely then evaluated by:

a. The presentation of the training material received a good response; there are many questions from the participants.

b. Joint Community Service activities follow by evaluated with filling out a questionnaire.

\section{CONCLUSION AND SUGGESTION Conclusion}

a. Overall, the event which was held online was welcomed by the participants consisting of SME business actors. The participants seemed very enthusiastic about participating in the event and asked a lot of questions. And there was an interactive discussion with the speakers.

b. The atmosphere of the online training was conducive, participants listened to the material presented by the speakers and listened well and understood the material presented.

c. Overall, the participants stated that the SME training activities were very useful, there were many "new" things that were obtained and learned during the activity. Interesting training materials are delivered so that participants are interested in following through to completion. 


\section{Suggestion}

Suggestions proposed for further community service activities are that these community service activities can be carried out for a wider target area with a greater number of participants and they have ability to manage SME financial.

\section{REFERENCES}

Budiantoro, H., Sari, I., Hukama, L. D., Zain, E., \& Simon, Z. Z. (2019). Pelatihan Pengelolaan Keuangan Bagi Ibu-Ibu Rumah Tangga Dan Kader Pkk Rt 16 Rw 04 Kelurahan Cempaka Putih Timur. SELAPARANG Jurnal Pengabdian Masyarakat Berkemajuan, 2(2), 24. https://doi.org/10.31764/jpmb.v2i2.882

Burgess, S., \& Paguio, R. (2016). Examining ICT application adoption in Australian home-based businesses: An innovation-decision process approach. Journal of Enterprise Information Management, 29(2), 276-299. https://doi. org/10.1108/JEIM-02-2014-0012

Danes, S. M., \& Hira, T. K. (1987). Money Management Knowledge of College Students. Journal of Student Financial Aid, 17(1), 3-16.

Drotar, D. (2011). Writing Research Articles for Publication. 347-374. https://doi.org/10.1007/9781-4615-4165-3_16

H., S. (2020). COVID-19 and corporate performance in the energy industry - Moderating effect of goodwill impairment. Energy Research Letters, 1.

Hutcehson (2008). Dirty Little Secrets of Family Business. Harvard Business Review. http:// dirtylittlesecretsoffamilybusiness.com/
Putra, Y. M. (2019). Analysis of Factors Affecting the Interests of SMEs Using Accounting Applications. Journal of Economics and Business, 2(3), 818-826. https://doi.org/10.31014/aior.1992.02.03.129

Rekarti, E., \& Doktoralina, C. M. (2017). Improving Business Performance: A Proposed Model for SMEs. European Research Studies Journal, 20(3), 613-623.

Ridwan, M. (2015). The Handbook of Family Financial Planning: Mengelola Keuangan Keluarga Secara Islami. Febi UIN-SU Press.

Saragih, R. (2017). Membangun Usaha Kreatif, Inovatif dan Bermanfaat melalui Penerapan Kewirausahaan. Jurnal Kewirausahaan, 3(2), 26-34. Retrieved from http://jklmii.org

Shen, H., Fu, M., Pan, H., Yu, Z., \& Chen, Y. (2020). The Impact of the COVID-19 Pandemic on Firm Performance. Emerging Markets Finance and Trade, 56(10), 2213-2230. https://doi.org/10.1080/ 1540496X.2020.1785863

Sumiarni, L. (2019). Perilaku Self-Control dalam Mengelola Keuangan Pribadi (Berdasarkan Theory Of Planned Behavior dan Conscientiousness) di STIKes Merangin. Ekonomis: Journal of Economics and Business, 3(2), 105. https://doi.org/10.33087/ ekonomis.v3i2.69

Williams, M. D., Dwivedi, Y. K., Lal, B., \& Schwarz, A. (2009). Contemporary trends and issues in IT adoption and diffusion research. Journal of Information Technology, 24(1), 1-10. https://doi. org/10.1057/jit.2008.30 